\title{
PERAN LEMBAGA PUSAT PELAPORAN DAN ANALISIS TRANSAKSI KEUANGAN DALAM PENAGGULANGAN TINDAK PIDANA MONEY LAUNDERING
}

\author{
I Wayan Panca Eka Darma, I Made Minggu Widyantara, Ni Made Sukaryati Karma \\ Fakultas Hukum Universitas Warmadewa, Denpasar-Bali, Indonesia
}

\begin{abstract}
Abstrak
Tugas, wewenang, fungsi dan tindak pidana Money laundering di Indonesia diatur dalam Undang-undang No. 8 Tahun 2010 tentang Pencegahan dan Pemberantasan Tindak Pidana Money laundering. Penelitian ini menelaah dua isu: peran lembaga PPATK dalam melakukan penanggulangan pencucian uang (money laundering) setelah diberlakukannya Undang-undang No. 8 Tahun 2010 tentang Pencegahan dan Pemberantasan Pencucian Uang dan sanksi pidana terhadap pelaku tindak pidana (money laundering) di Indonesia. Penelitian ini menggunakan metode hukum normatif, sebuah proses menemukan aturan hukum, prinsip-prinsip hukum, maupun doktrindoktrin hukum guna menjawab isu hukum yang di kaji dengan pendektan peraturan perundang-undangan. PPATK adalah lembaga bebas yang mempuyai 3 peranan pokok dalam pencegahan dan pemberantasan pencucian uang, yakni: menerima laporan terhadap tranksaksi keuangan yang mencurigakan, melakukan analisis atas laporan yang diterima dari pihak pelapor, dan meneruskan hasil analisis laporan kepada pihak yang berwenang. Pasal 2 ayat 1 jo Pasal 18 Undang-Undang Nomor 31 Tahun 1999 tentang Pidana Korupsi sebagaimana telah diubah menjadi Undang-undang Nomor 31 Tahun 2001 tantang Perubahan Atas UndangUndang Nomor 31 Tahun 1999 jo Pasal 55 ayat 1 KUHP. Subsidiair Pasal 3 jo Pasal 18 Undang-Undang Nomor 31 Tahun 1999 tentang Pemberantasan Tindak Pidana Korupsi sebagaimana telah diubah menjadi Undang-Undang Nomor 20 tahun 2001 tentang Perubahan atas Undang-Undang Nomor 31 Tahun 1999 jo Pasal 55 ayat 1 KUHP. Kedua, Pasal 3 ayat (1) huruf g of Undang-Undang Nomor 25 Tahun 2003 tentang Perubahan atas Undang-Undang Nomor 15 Tahun 2002 tentang Tindak Pidana Pencucian Uang jo Pasal 55 ayat (1) KUHP.
\end{abstract}

Kata Kunci: Money laundering; Penanggulangan; PPATK; Tindak pidana

\begin{abstract}
The duties, authorities, functions and criminal acts of money laundering in Indonesia are regulated in Law No. 8 of 2010 concerning the Prevention and Eradication of Criminal Acts of Money laundering. This study examines two issues: the role of the PPATK agency in combating money laundering after the enactment of Law No. 8 of 2010 concerning the Prevention and Eradication of Money laundering and criminal sanctions against perpetrators of criminal acts of money laundering in Indonesia. This research uses normative legal method, a process of finding legal rules, legal principles, and legal doctrines in order to answer the legal issues under study from the perspective of statutory regulations. PPATK is an independent agency that has 3 main roles in the prevention and eradication of money laundering, namely: receiving reports on suspicious financial transactions, analysing the reports received from reporting parties, and forwarding the results of report analysis to the authorised party. Article 2 paragraph 1 jo Article 18 of Law Number 31 of 1999 concerning Criminal Acts of Corruption as amended into Law Number 31 of 2001 concerning the Amendment to Law Number 31 of 1999 jo Article 55 paragraph 1 of the Criminal Code. Subsidiarily Article 3 jo Article 18 Law Number 31 of 1999 concerning Eradication of Corruption Crime as amended to Law Number 20 of 2001 concerning the Amendment to Law Number 31 of 1999 jo Article 55 paragraph 1 of the Criminal Code. Secondly, Article 3 paragraph (1) letter g of Law Number 25 of 2003 concerning the Amendment to Law Number 15 of 2002 concerning the Criminal Acts of Money laundering jo Article 55 paragraph (1) of the Criminal Code.
\end{abstract}

Keywords: Money laundering; overcoming; PPATK; Criminal act 


\section{PENDAHULUAN}

Indonesia merupakan negara hukum dalam arti negara harus memberikan perlindungan kepada warga negaranya dalam segala aspek dalam berkehidupan (Astawa, 2006; Sujatmoko, 2010; Fitriani, 2016), berbangsa dan bernegara. Maka dari itu Negara Indonesia menjunjung tinggi nilai hukum yang memiliki tujuan agar tercapainya keadilan, kepastian dan kemanfaatan. Indonesia merupakan negara berkembang yang dengan gencar sedang melakukan perkembangan dalam bidang ekonomi. Dalam perkembangan ini perekonomian berkembang dengan sangat pesat yang ditandai dengan perkembangan dalam dunia teknologi informasi, yang juga berdampak pada perekonomian yang semakin mendunia dan disertai dengan peningkatan finansialnya (Okamoto \& Sjöholm, 2001; Muchdie, 2016). Lalu lintas antar negara (cross boarder nations) memudahkan perkembangan perekonomian yang terintregasi melalui teknologi komunikasi yang dapat dilakukan dengan waktu yang sangat singkat (Kurniadi, 2009; Setiawan, 2017).

Pada dasarnya perkembangan perekonomian ini menimbulkan suatu dampak yang cukup buruk yaitu timbulnya kejahatan dengan cara dan melalui media yang baru serta bersifat lintas negara. Dampak dari perkembangan ini telah banyak mencipakan kejahatan seperti korupsi, kejahatan perbankan, perpajakan dan kejahatan yang dapat dilakukan perseorangan atau kelompok.

Dalam tindak kejahatan ini dapat membuat pelaku memiliki kekayaan yang berlimpah maka pelaku berusaha untuk menyembunyikan kekayaan tersebut dengan memasukkan dalam bentuk financial (financial system) dan pertama masuk kedalam bentuk perbankan (banking system) hal seperti ini biasa disebut dengan pencucian uang (money laundering). Hal seperti ini sudah lama diketahui oleh publik diawali dari negara USA pada Tahun 1830. Hal ini telah di atur dalam UU No. 25 Tahun 2003 tentang pencucian uang karena dampak yang telah ditimbulkan (Suranta, 2010: 52) bahwa tindak pidana pencucian uang ini merupakan perbuatan yang sama sekali tidak dapat dipisahkan dari perbuatan asalnya. Menurut Irman, kejahatan pembasuhan dan tidak akan ada kalau tanpa hasil dari adanya kejahatan asal (Irman, 2007: 5).

Berdasarkan uraian di atas, bisa disimpulkan bahwa kejahatan akan selalu ada karena dibantunya faktor perkembangan teknologi dan cara berkomunikasi yang dimana kejahatan yang semakin canggih pula. Oleh karena itu, tindak kejahatan terhadap pencucian uang ini memerlukan pemahaman/pengertian yang lebih spesifik lagi serta peraturan apa saja yang digunakan dalam upaya menindaklanjuti aksi kejahatan tersebut oleh aparat penegak hukum serta upaya penanggulangannya.

Kajian tentang money laundering dan peran PPATK dalam penanganannya memang bukan merupakan satu informasi yang baru muncul dalam dunia kajian ilmiah. Kajian-kajian yang pernah diluncurkan ialah kajian yang dilakukan oleh Khairul dkk. (2011), Rahayuningsih (2013), dan Darmawan (2015). Masing-masing penelitian ini memang mengkaji tentang peran lembaga tersebut. Akan tetapi tidak mengkaji secara komprehensif tentang sanksi pidana yang mesti dijatuhkan kepada pelaku tindakan money laundering. Dalam praktik pemutusan sesuatu perkara di pengadilan terkadang tindak pidana tersebut tidak mendapat sanksi yang setimpal sesuai yang diatur dalam Undang-Undang yang berlaku.

Berdasarkan latar belakang yang telah diuraikan, rumusan masalah penelitian ini sebagai berikut:

1. Bagaimana peran lembaga pusat pelaporan dan analisis transaksi keuangan dalam penanggulangannya tindak pidana money laundering.

2. Bagaimana sanksi pidana terhadap tindak pidana money laundering di Indonesia.

Tujuan dari penelitian ini ialah:

1. Untuk mengetahui serta menelaah peran lembaga pusat pelaporan dan analisis transaksi keuangan dalam penanggulangan money laundering.

2. untuk mengetahui penerapan sanksi pidana terhadap tindak pidana money laundering di Indonesia.

\section{METODE PENELITIAN}

Sebagaimana yang telah diuraikan di atas, dalam mencapai tujuan penelitian ini digunakan metode normatif, yang merupakan suatu metode penelitian yang terealisasi dengan meneliti bahan pustaka hukum yang ada. Bahan hukum yang digunakan bersumber dari penelitian kepustakaan berupa:

1. bahan hukum primer yang berdasarkan KUHP, Undang- undang No. 25 tahun 2003, UU No. 8 Tahun 2010, dan UU No. 10 Tahun 1998. 
2. bahan hukum sekunder yang diperoleh dari buku-buku, tesis, jurnal dan dokumen-dokumen yang mendukung dari penelitian ini.

Data penelitian ini dianalisis dengan metode analisis data kualitatif dengan teknik interpretasi. Data-data yang berupa ketentuan-ketentuan hukum diinterpretasikan dengan disesuaikan pada bentuk-bentuk kejahatan money laundering dan motif pelaksanaannya. Hasil analisis disajikan dengan metode informal, dalam arti, data disajikan menggunakan kata-kata dalam susunan dan urutan sistematis.

\section{HASIL DAN PEMBAHASAN}

\section{Peran Lembaga Pusat Pelaporan dan Analisis Transaksi Keuangan dalam Penanggulangan} Tindak Pidana Money laundering

Dalam pelaksanaan wewenang PPATK mempunyai fungsi yang berkaitan dengan pencegahan dan pemberantasan pencucian uang atau disebut money laundering. Tujuan dibentuknya lembaga tersebut ialah untuk menghindari kecenderungan pada hukum positif dan diperlukannya sistem penegakan hukum yang perlu bersentuhan secara filosofis. Oleh karena itu proses ini harus dikaji metafisik dan aksiologisnya agar diketahuinya apa hakikat dari pembentukan lembaga negara dan fungsi lembaga tersebut (Susanto, 2011).

Pada hakikat tujuan utama terbentuknya PPATK ialah melaksanakan pengawasan dan penumpasan tindak kejahatan Pencucian Uang. Berarti hal ini PPATK telah mewajibkan jasa keuangan untuk melaporkan dan mengawasi para pelaku kejatahan yang bisa saja terindikasi melakukan tindak kejahatan pencucian uang. Unuk itu ketelitian dan kehati-hatian sangat diperlukan agar terhindar dari pemanfaatan bentuk finasial menjadi media untuk melakukan pembasuhan dana. Saat menjalankan tugasnya PPATK menganalisa transaksi keuangan tunai maupun non-tunai atas dasar pemerintah maupun inisiatif sendiri. Secara singkat alur kerja PPATK dimulai dari pelapor yang telah berkewajiban untuk melaporkan setiap transaksi keungan tunai yang minimal bernominal Rp. 500.000.000,00,- (lima ratus juta rupiah) atau dengan mata uang lain yang jumlahnya hampir sesuai dalam wujud transaksi yang mencurigakan serta transaksi dari di negeri sendiri maupun yang berada di luar negara. Setelah lembaga negara mendapat laporan dari pelapor maka akan segera diproses ke pihak yang berwajib, dan tetap mengikuti ketentuan yang sama dengan tindak kejahatan awal. Seperti yang telah diketahui bahwa tindak kejahatan awal yang berpotensi berbentuk pencucian uang seperti korupsi, penyelundupan manusia, suap dan narkotika.

Kedudukan dan wewenang PPATK ini telah diatur dalam Undang-undang yang berlaku dimana kedudukan PPATK terdapat dalam aspek tempat atau kewilayahan dan struktur dalam kenegaraan yang telah diatur dalam Pasal 1 dan 37 UU No. 8 tahun 2018 serta wewenang PPATK yakni melawan dan membasmi Tindak Kejahatan Pencucian Uang yang sudah tertera pada aturan 39 and aturan 44 UU No. 8 tahun 2010.

\section{Sanksi Pidana terhadap Pelaku Tindak Pidana Money Laundering di Indonesia}

Menurut Pasal 2 Ayat (1) UU No. 25 Tahun 2003 ataupun Pasal 2 Ayat (1) UU No. 8 Tahun 2010, jenis-jenis tindak pidan a kejahatan yang menghasilkan asal kekayaan yang disebut juga sebagai tindak kejahatan asal yang telah menghasilkan kekayaan yang sangat besar dan tindak pidana asal inilah yang menjadi dasar apakah suatu transaksi akan dijerat pidana atau tidak (Arief, 2004). Tindak kejahatan awal dari pencucian uang ini yaitu tindak kejahatan biasa dalam hal membuat dana serta aset menjadi besar sebagaimana yang telah tertera pada aturan 2 Ayat (1) UU No. 8 Tahun 2010. Kejahatan ini bisa dilakukan oleh perseorangan maupun kelompok meliputi korupsi, penyuapan, narkotika, psikotropika, penyelundupan tenaga kerja, penyelundupan imigran, bidang perbankan, pasal modal, asuransi, cukai, perdagangan manusia, perdagangan senjata ilegal, penggelapan, penipuan, perjudian, prostitusi, dan terorisme serta tindak pidana yang diancam dengan pidana penjara 4 empat) tahun atau lebih, yang dilakukan di wilayah NKRI atau di luar wilayah Negara Indonesia dan tindak pidana tersebut termasuk dalam tindak pidana menurut hukum di Negara Kesatuan Republik Indonesia. berikut:

Syarat-syarat pengawasan dan penumpasan tindak kejahatan pencucian uang adalah seperti 
1. harta kekayaan yang diperoleh berdasarkan tindak pidana yang telah disebutkan pada Pasal 2 Ayat (1) UU No. 8 Tahun 2010 dan juga tindak pidana yang memiliki pidana kurungan penjara 4 tahun atau lebih.

2. tindak pidana ini telah disebutkan harus dilakukan di Negara Indonesia atau di luar Negara asalkan tindak kejahatan tersebut juga menjadi tindak pidana menurut hukum di Negara Indonesia.

Undang-undang No. 8 Tahun 2010 tentang Tindak Pidana Pencucian Uang mengatur tentang pencegahan dan pemberantasannya, yang mana, dalam aturan ini terdapat kejahatan yang dilakukan individu ataupun kelompok yang berada dalam wilayah Indonesia maupun di luar wilayah Indonesia. Harta kekayaan yang telah dihasilkan dari tindak pidana yang menjadi asal dari tindak pidana pencucian uang ini pada umumnya tidak akan langsung digunakan/ dibelanjakan karena jika hal tersebut dilakukan maka akan lebih mudah dilacak oleh penegak hukum mengenai dimana sumber harta tersebut, sehingga para pelaku lebih dahulu mengusahakan agar harta mereka lebih dahulu masuk ke dalam sistem keuangan. Dengan demikian, asal usul dari harta kekayaan itu akan tidak mudah untuk diketahui oleh penegak hukum. Dalam UU TPPU tindak pidana money laundering dibedakan menjadi dua tindak kejahatan, yakni:

1. Tindak kejahatan pencucian aktif, yakni setiap individu yang meletakan, mentransfer, mengubah, membelanjakan, membayarkan, menghadiahkan, dan mengalihkan dengan aset atau surat-surat berharga lain atas harta kekayaan yang telah terbongkar. Tindak kejahatan pencucian uang juga akan dikenakan bagi siapapun yang telah menikmati hasil dari tindak pidana ini dan siapapun yang berusaha menyembunyikan riwayat kejahatan. Awalnya, kepemilikan yang pada hakekatnya atas aset tersebut dipidana dengan penahanan dalam penjara paling lama 20 (dua puluh) tahun dan dengan denda paling banyak Rp. 5.000.000.000,00,- (lima miliar rupiah).

2. Tindak kejahatan pencucian uang pasif yang dikenakan untuk setiap individu yang telah memberi atau memiliki aset yang telah terbukti dari hasil tindak kejahatan pencucian uang. Pihak tersebut dipidana penjara paling lama 5 (lima) tahun penjara dan denda paling banyak Rp. 1.000.000.000,00,- (satu miliar rupiah).

Secara umum mengapa kejahatan pencucian uang (money laundering) harus diperangi dan merupakan tindak kejahatan adalah karena hasil dari tindak pidana ini berdampak negatif pada sistem keuangan dan perekonomian dunia. Dengan dinyatakannya pencucian uang sebagai tindak kejahatan maka pihak berwenang akan lebih dimudahkan dalam mensita aset yang dihasilkan dari tindak pidana ini. Karena sulitnya untuk dilacak dan/atau sudah dipindahtangankan, dengan dinyatakannya pencucian uang sebagai tindak pidana dan dengan adanya pelaporan transaksi yang mencurigkan maka pihak berwenang lebih mudah untuk menemukan dalang dari tindak pidana yang telah terjadi. Oleh sebab itu, berhubung setiap tindak pidana memiliki unsur melawan hukum, pertanggungjawaban juga diarahkan kepada sifat melawan hukum. Atas dasar ketentuan inilah segala perbuatan tindak kejahatan berupa menyamarkan/menyembunyikan harta kekayaan dan memiliki sifat melawan hukum tersebut termasuk dalam delik atau tindak pidana.

Undang-Undang No. 8 Tahun 2010 telah mengontrol ketentuan money laundering sebagai tindak kejahatan yang persyaratan untuk deliknya dibagi menjadi dua tindak pidana yaitu: tindak pidana pencucian uang yang diatur dalam BAB II dengan judul Tindak Kejahatan Pencucian Uang mulai dari pasal 3 hingga pasal 10. Tindak Pidana Lain yang berkaitan dengan Tindak Pidana Pencucian Uang ini diatur pada BAB II, yaitu Pasal 11-16 di mana aturan ini hanya terbatas pada orang saja.

Berdasarkan pada aturan Pasal 3 sampai 10 Undang-Undang Nomor 8 Tahun 2010, yang tercantum ke dalam unsur-unsur tindak kejahatan pencucian uang adalah: pertama, kelompok baik individu, korporasi maupun personil pengendali korporasi; kedua, dari akibat perbuatan tindak pidana yang disamarkan ke aset itu patut diketahui dan diduga sebagai hasil tindak pidana sebagaimana ditentukan dalam Pasal 2 Ayat (1) UU Nomor 8 Tahun 2010 (Syamssudin, 2011).

Dalam Vonis Pengadilan Nomor: 339/PID.B/2010/PN.JKT.PST dinyatakan bahwa telah terjadi tindak pidana korupsi dan tindak pidana pencucian uang yang pelakunya ialah antara Alias ALWARRAQ. AlS. RAFAT ALI RIZVI bersama pihak ketiga ROBERT TANTULAR. Para Tersangka I dan II antara tahun 2001-2008 yang bertempat di kantor PT Bank CIC dan atau di kantor PT Bank Century Gedung Sentral Senayan II, Jalan Asia Afrika No. 8 Jakarta, mengadakan atau ikut 
serta melaksanakan dengan melanggar hukum memperbanyak aset atau harta kekayaan untuk diri sendiri atau orang lain atau suatu korporasi yang dapat merugikan keuangan pemerintah dengan melaksanakan negosiasi pembelian, peletakan, dan atau peralihan surat-surat berharga Valuta asing (SSB valas) Bank CIC. Sebagian dokumen berharga ini terbilang dalam structured product yang tidak memiliki nilai dan juga dikenal dengan sebutan non-rating, tidak mempunyai harga pasar dan menawarkan imbalan hasil yang rendah. Pada saat surat tersebut jatuh tempo, Bank CIC tidak menerima dana secara tunai melainkan dengan melakukan pembayaran dengan saham perusahaan Global Opportunities Fund yang dimiliki terdakwa II.

Dalam kasus ini Terdakawa I dan II didakwa oleh jaksa penuntut umum dengan dakwaan kumulatif; dimana pembuktian harus dilakukan secara sendiri-sendiri. Majelis Hakim membuktikan surat dakwaan kesatu dan kedua yaitu primair melanggar Pasal 2 Ayat 1 jo Pasal 18 UndangUndang Nomor 31 Tahun 1999 tentang Pidana Korupsi sebagaimana telah diubah dengan Undangundang Nomor 31 Tahun 2001 tentang Perubahan atas Undang-undang Nomor 31 Tahun 1999 jo Pasal 55 Ayat 1 ke-1 KUHP. Subsidiair Pasal 3 jo Pasal 18 Undang-Undang Nomor 31 Tahun 1999 tentang Pemberantasan Tindak Pidana Korupsi sebagaimana telah diubah dengan UndangUndang Nomor 20 TAHUN 2001 tentang Perubahan Atas Undang-Undang Nomor 31 Tahun 1999 jo Pasal 55 Ayat 1 ke-1 KUHP. Kedua, Pasal 3 Ayat (1) Huruf g Undang-Undang Nomor 25 TAHUN 2003 tentang Perubahan atas Undang-Undang Nomor 15 Tahun 2002 tentang Tindak Pidana Pencucian Uang jo Pasal 55 Ayat (1) ke-1 KUHP menentukan dalam vonis pidana "IN absentia" No. 399/Pid.B/2010/PN-JKT.PST telah diputus pada persidangan yang dinyatakan terbuka untuk publik. Dalam isi putusan bahwa harta atau aset dari Robert Tantular dan istrinya akan dirampas untuk negara. Sebagaimana dimuat dalam Putusan pada halaman 253 karena Robert Tantular bersama-sama dengan Rafat Alih Rizvi mendatanggani Letter of Commitment (LOC), pada tanggal 16 November 2018 (bukti P-2a dan 2b).

Alasan-alasan tersebut tidak dapat dibenarkan oleh karena judex fact salah menerapkan hukum tentang keberatan pihak ketiga atas perampasan harta kekayaan yang bukan kepunyaan pemohon Kasasi: Robert Tantular, MBA., yang saat ini bersetatus Terpidana di Lapas Salemba Jakarta dalam perkara pokok atas nama Tersangka I Hesham Talaat Mohamed Besheer Al Warraq alias Hesham Al Warraq dan Terdakwa II Rafat Ali Rizvi yang diadili secara in absentia dan dinyatakan sudah terbukti bersalah melakukan perbuatan tindak kejahatan "Korupsi dan Pencucian Uang Secara Bersama-sama" serta dijatuhi pidana penjara masing-masing selama 15 (lima belas) tahun dan membayar uang pengganti masing-masing sejumlah Rp. 3.115.889.000.000,- (tiga miliar seratus lima belas juta delapan ratus delapan puluh sembilan juta rupiah).

\section{SIMPULAN DAN SARAN}

\section{Simpulan}

Terdapat dua simpulan yang ditarik dari penelitian ini:

1. Peran lembaga Pusat Pelaporan dan Analisis Transaksi Keuangan (PPATK) dalam melakukan penanggulangan dan pemberantasan pencucian uang lebih ditekankan pada perlindungan aspek ekonomi agar perekonomian di Indonesia tidak mengalami kerugian yang signifikan di sektor keuangan negara. Dari hasil kejahatan, para pelaku melakukan penempatan dari hasil kejahatan yang berupa harta kekayaan, yang awalnya uang kotor (dirty money) menjadi uang bersih (clean money) melalui penempatan pada system perbankan. PPATK adalah lembaga independent yang mempuyai 3 (tiga) peranan pokok dalam pencegahan dan pemberantasan pencucian uang dengan cara menerima laporan terhadap tranksaksi keuangan yang mencurigakan, melakukan analisis atas laporan yang diterima dari pihak pelapor, dan meneruskan hasil analisis laporan kepada pihak yang berwenang. Fungsi serta tugas PPATK tersebut diatur dalam pasal 30 sampai dengan pasal 44 Undang-Undang No. 8 Tahun 2010 tentang Pencegahan dan Pemberantasan Pencucian Uang.

2. Pelaku tindak kejahatan money laundering dapat dikenakan sanksi pidanaseperti yang diatur dalam Pasal 2 Ayat 1 jo Pasal 18 Undang-undang Nomor 31 Tahun 1999 tentang Pidana Korupsi sebagaimana telah diubah dengan Undang-undang Nomor 31 Tahun 2001 tantang Perubahan atas Undang-undang Nomor 31 Tahun 1999 jo Pasal 55 Ayat 1 ke-1 KUHP. Subsidiair Pasal 3 jo Pasal 18 Undang-Undang Nomor 31 Tahun 1999 tentang Pemberantasan Tindak Pidana 
Korupsi sebagaimana telah diubah dengan Undang-Undang Nomor 20 Tahun 2001 tentang Perubahan atas Undang-Undang Nomor 31 Tahun 1999 jo Pasal 55 Ayat 1 ke-1 KUH. Kedua Pasal 3 Ayat (1) Huruf g Undang-Undang Nomor 25 Tahun 2003 tentang Perubahan atas Undang-Undang Nomor 15 Tahun 2002 tentang Tindak Pidana Pencucian Uang jo Pasal 55 Ayat (1) ke-1 KUHP.

\section{Saran}

1. PPATK mesti meningkatkan pengawasan terhadap asset atau keuangan Negara dengan memanfaatkan teknologi yang mampu mendeteksi setiap tindak kejahatan tersebut seiring dengan kemajuan dalam kehidupan masyarakat yang ditandai dengan kamjuan dalam bidang teknologi dan komunikasi.

2. Penelitian selanjutnya akan berfokus pada solusi alternatif bagi pemerintah untuk mendeteksi tindak kejahatan money laundering. Peningkatan lapangan kerja akan dapat membantu meminimalisir kemungkinan bagi terjadinya tindak kejatahan baik dalam lembaga keuangan maupun lembaga atau aspek-aspek lain.

\section{DAFTAR PUSTAKA}

Arief, B. N. (2004). Beberapa Masalah Perbandingan Hukum Pidana. PT Raja Grafindo.

Astawa, I. D. R. (2006). Aspek Perlindungan Hukum Hak-hak Tenaga Kerja Indonesia di Luar Negeri [Universitas Diponegoro Semarang].

Darmawan, D. (2015). Peran PPATK dalam Penyidikan Tindak Pidana Pencucian Uang. Lex Crimen, 4(3), 1689-1699.

Fitriani, R. (2016). Anak dalam Melindungi dan Memenuhi Hak-hak Anak. Jurnal Hukum : Samudra Keadilan, 11(2), 250-258.

Irman, T. (2007). Praktik Pencucian Uang dalam Teori dan Fakta. MQS Publishing.

Khairul, Siregar, M., \& Marlina. (2011). Kewenangan PPATK dalam Pencegahan dan Pemberantasan Tindak Pidana Pencucian Uang. Jurnal Mercatoria, 4(1), 33-42.

Kurniadi, D. (2009). Strategi Pengembangan Wilayah Perbatasan Antarnegara: Memacu Pertumbuhan Ekonomi di Entikong Kabupaten Sanggau Provinsi Kalimantan Barat [Universitas Diponegoro].

Muchdie, M. (2016). The Contribution of Technology on Indonesian Economy: National, Sectoral and Spatial Perspectives. International Journal of Advanced Research, 4(11), 2149-2156.

Okamoto, Y., \& Sjöholm, F. (2001). Technology Development in Indonesia.

Rahayuningsih, T. (2013). Analisis Peran PPATK sebagai Salah Satu Lembaga dalam Menanggulangi Money Laundering di Indonesia. Yuridika, 28(3), 314-330.

Setiawan, A. B. (2017). Kebijakan Teknologi Informasi dan Komunikasi untuk Mendorong Pembentukan Model Bisnis Masa Depan. Journal Pekommas, 2(2), 193-204.

Sujatmoko, E. (2010). Hak Warga Negara dalam Memperoleh Pendidikan. Jurnal Konstitusi, 7(1), $182-211$.

Suranta, F. A. (2010). Peranan PPATK dalam Mencegah Terjadinya Praktik Money Laundering. Gramata Publikasi.

Susanto. (2011). Filsafat Ilmu Suatu Kajian dalam Demensi Ontologis, Epistemologis dan Aksiologis. Bumi Aksara.

Syamssudin, A. (2011). Tindak Pidana Khusus. Sinar Grafika. 